\title{
The role of prophetic action in public theology - the implications for addressing corruption in a context of sustainable development
}

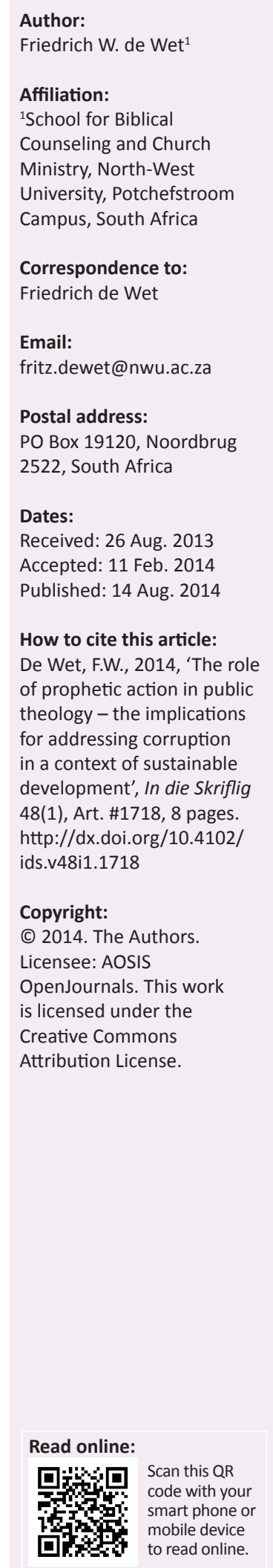

After almost two decades of democratic rule in South Africa, patterns of withdrawal and uncertainty about the complexities involved in defining the contents, rationality and impact of the public role of the church in society seem to be prevalent. As unabated levels of corruption and its sustained threat to sustainable development point out, a long-awaited reckoning should take place - at least in the circles of South African churches from reformed origin - regarding its rich tradition of critical and transformational prophetic involvement in the public space. In this article, the author places different models for the public role of the church in the field of tension that is generated when the private and public spheres meet each other. The author anticipates different configurations that will probably form in this field of tension in the cases of respectively the Two Kingdoms Model, the Neo-Calvinist Approach and the Communicative Rationality Approach.

Die rol van profetiese prediking in publieke teologie: Die implikasies vir die hantering van korrupsie in 'n konteks van volhoubare ontwikkeling. Na bykans twee dekades van demokratiese regering in Suid-Afrika blyk dit dat patrone van onttrekking en onsekerheid oor wat die inhoud, rasionaliteit en impak van die publieke rol van die kerk in die samelewing presies behels, steeds voortduur. In ' $n$ situasie waaruit dit blyk dat daar geen werklike teenvoeter is vir die hoë vlakke van korrupsie asook vir die bedreiging wat dit vir volhoubare ontwikkeling inhou nie, is dit hoog tyd dat die kerk, ten minste in die geval van die Suid-Afrikaanse kerke van reformatoriese oorsprong, diep oor sy profetiese rol in die samelewing moet besin. Hierdie kerke kom uit 'n ryke tradisie van kritiese en transformerende betrokkenheid in die publieke sfeer. In hierdie artikel plaas die outeur verskillende modelle vir die publieke rol van die kerk in die spanningsveld wat gegenereer word wanneer die private en publieke sfere mekaar ontmoet. Die outeur antisipeer verskillende konfigurasies wat waarskynlik na vore sal tree in hierdie spanningsveld in die gevalle van onderskeidelik die Twee Koninkryke Model, die Neo-Calvinistiese Benadering en die Kommunikatiewe Rasionaliteit Benadering.

\section{Introduction}

The transition from apartheid to a non-racial liberal democracy in South Africa has reshaped public life to such an extent that it inevitably requires different theological responses to those that were deemed or proven to be appropriate within a totalitarian apartheid context. Whereas previously the liberation struggle and criticism against the totalitarian-justifying theological design was the core around which the theological debate centred, the focal point has now shifted to democratic transformation and, within that, to the enormous challenge of inequality and poverty (cf. De Gruchy 2004:47, 54).

The implications of this rapidly changing landscape in a democratic dispensation characterised by secularity ${ }^{1}$ seem to have caught churches' leadership off guard regarding a new vision for the prophetic role in the renewal of society. Once the 1994 elections had put the ANC government in power, the churches, as Mayson (2000:59) reminds us, seemed to back off. The prophetic vision that was prevalent during the struggle years collapsed. Hopes that religion would play a major role in the new dispensation were disappointed. Conferences to determine that role were not followed through. The national consultation of churches in South Africa at Rustenburg on 22-26 February 1999, for example, involved almost all Christian churches. A joint declaration was issued about human rights and human responsibilities, poverty, crime and violence, respect

1.The difference between the terms secularity and secularism should be noted. Secularity is meant to indicate a formal commitment to how different claims ought to be assessed, namely by appeal to human reason and common experience rather than by appeal to the authority of the church, tradition or political position. In contrast, secularism indicates a substantive outlook that denies the validity of religious claims, per se, such as claims about the reality of God (Meyer 2010:2). 
for life and education. It is striking how little attention it received in the media and from the public when compared to the powerful impact of the first Rustenburg consultation before the 1994 election (Pieterse 2000:86; cf. Smit 2003:233). The previous high regard for the voice of the church was now relegated to viewing it as just one voice amongst others. Disillusionment with this new relegated role as well as the idea that Christians, after years of suffering and struggle, had spent their role and were entitled to sit back and let the new government transform society for them within the safe bounds of the Constitution, made churches turn their eyes inward to promote the growth of religious institutions rather than the transformation of society (Mayson 2000:59).

After almost two decades of democratic rule in South Africa, patterns of withdrawal and uncertainty about the complexities involved in defining the contents, rationality and impact of the public role of the church in society still seem to be prevalent.

In this article, the problem field will be addressed from the vantage point of practical theology as a scientific endeavour not only concerned with the inner working of the church, but also with the public implications of the Gospel for this world in its current form and in its destiny: ${ }^{2}$

- Different epistemological models for coming to grips with the complex landscape of the prophetic role of the church in the public sphere of democratic societies will be investigated in interaction with global trends in Western thinking regarding this issue.

- The reasoning behind these epistemological models will, from a practical-theological point of view, consistently be placed in the tension that arises when the private sphere (with its emphasis on actions that freely express the own ethos) and the public sphere (with its emphasis on the space shared with interest groups that do not necessarily share similar views, but can potentially benefit from one's own views and actions) come into interaction with each other. ${ }^{3}$ Hermans (2005) expresses the dynamics of this tension-field as follows:

On the one hand one needs to be truthful to normative claims of a religious community and tradition; but on the other hand one needs to be involved in an open dialogue with persons who do not share the metaphysical ground of this claim. How can one sail between Scylla of being strongly distinct but publicly irrelevant and Charybdis of being relevant but to relinquish its distinct truth claim? (p. 219)

2.See Miller-McLemore (2005:102) for a discussion on a growing trend in practical theological thinking to move towards public theology. Factors like concern about the silence of mainstream Christianity on key social issues and growing awareness of the serious limitations of approaches that merely focus on the skills of individual clergy, led practical theologians towards a focus on conceptual strategies for the transformation of culture.

3.Baker and Reader (2009:228) envisage a theological space that is both interdisciplinary and multilayered, working simultaneously at the intersect of a number of key political, cultural and theological realities. In order to express the full dynamism and complexity of what is required of practical theology and public full dynamism and complexity of what is required of practical theology and public theology, they identify five sets of binary poles and describes Christian interaction as a movement between the public and the private, the global and the local, the secular and the sacred, the creative (with risk involved) and the painful (with the predicament of being contested involved), the resurrection and the crucifixion. In doing so, an attempt is made to resist the simplistic and partial analysis of contemporary life that opts for engagement with only one or the opposite side of the binary pole.
- The way in which the abovementioned tension is navigated in the case of each of the different epistemological approaches under investigation will have a decisive impact on the visualisation of the role of prophetic action. Therefore, conclusions will be drawn in each case regarding the likely role that will be visualised for prophetic action by church leaders. The dynamics of corruption in its implications for sustainable development as one of the most challenging issues that needs to be addressed by all role players in the public arena of the current South-African democratic environment will consistently be used as example.

Before embarking on this practical-theological exercise, the current dynamics of corruption in its implications for sustainable development ${ }^{4}$ in South Africa's liberal democracy are briefly discussed.

\section{The dynamics of corruption and sustainable development in South Africa's liberal democracy}

Although the concept of liberal democracy ${ }^{5}$ aims at providing justice and equal opportunities for all people in a particular society, it is apparent that even this refined form of political system cannot guarantee a better life for all. One example of a notoriously undemocratic element at work, even in countries noted for their free, open, and democratic societies, is the prevalence of endemic corruption. The 2012 Corruption Perceptions Index of Transparency International ${ }^{6}$ rates South Africa, one of the younger liberal democracies of the world, 69th out of 176 countries with a score of 43 on a scale of 1 to 100 (where 0 means a country is perceived to be highly corrupt and 100 means it is perceived to be very clean). From the Index, it becomes clear that two-thirds of countries included in the survey are rated below 50, indicating a serious corruption problem on a global scale.

The negative impact of various forms of corruption on the current state of the South-African society and its future sustainability cannot be denied. Instances of corruption in South Africa, like the allocation of public resources for private financial gain or the establishment of inferior infrastructure due to the so-called 'tenderpreneurship' system, ${ }^{7}$ leave millions of poor South-Africans in a very vulnerable

4.The factor of sustainable development (which consists of managing resource use for the benefit of current as well as future generations to such an extent that human needs are met without overburdening the environment in the process) is consciously view on the future of society. One of the distinct features of prophetic action is that view on the future of society. One of the distinct features of prophetic
it is deeply rooted in anticipation of the eschatological renewal of life.

5.The key ideas in the concept of liberal democracy, in addition to equal protection before the law, involves: (1) freedom for each person to live in accordance with his or her own interpretation of life and (2) the state's neutrality with respect to all such perspectives on life (Volf 2011:124).

6.The report views corruption as a major threat facing humanity, translating into human suffering with poor families being extorted for bribes to see doctors or to get access to clean drinking water. It leads to failure in the delivery of basic services like education or healthcare. It derails the building of essential infrastructure as corrupt leaders skim funds (Transparency International n.d.).

7.'Tenderpreneurs' are persons who enrich themselves by gaining contracts in an illegal way or as a result of nepotism, political loyalties and pro-struggle credentials. Funds that were intended for low-cost housing, job creation and improved service Funds that were intended for low-cost housing, job creation and improved service
delivery are misappropriated with the result that inferior, poorly sustainable delivery are misappropriated with the res
infrastructure is created (Vorster 2012:136). 
position, deepen economic inequality and seriously threaten sustainable development (De Klerk 2013). It can be said that a perpetual culture of corruption has taken root in the South-African society, a culture that has invaded all spheres of life. It does not only have a severe economic impact, but also promotes distrust in leadership and fosters a spirit of despondency, posing great challenges to whoever wishes to address this issue with academic theory-formation, political prowess or innovative church leadership.

Vorster (2012:136) discusses the probability that the presence of a robust legal culture and uncompromised religions will contribute to reduced levels of corruption in a particular society. ${ }^{8}$ It is, however, noticeable in the South-African context, as Vorster (2012) points out, that Protestantism, especially the influential reformed tradition, played a minor role in monitoring the governments of both the pre-1994 and the post-1994 dispensations. Protestantism was unable to inhibit both the corruption pre-1994 and the contemporary levels of this phenomenon. This assessment by Vorster (2012) confirms that a long-awaited reckoning should take place, at least in the circles of South-African churches from reformed origin, regarding its rich tradition of critical and transformational involvement in the public space.

McIlhenny (2009:76) draws a helpful distinction between two epistemological approaches in reformed confessional communities regarding the role and influence of Christianity in the public sphere. In the Two Kingdoms Model, the emphasis is on Christians recognising the entanglements of sin in culture and their pilgrim state on earth, turning their focus away from transformation, living in the hope that God will restore heaven and earth, and working faithfully and diligently to bring peace to all parts of the world. In the Neo-Calvinist Model, the sovereignty of Christ in all areas of life is emphasised and Christians are urged to actively engage culture with a view on its spiritual transformation. No area of life is neutral and all areas need to be redeemed.

In the discussion of the spectrum of possible epistemological departure points for defining the role of prophetic action in the public square, McIlhenny's broad distinction in discussing epistemologies that work with a dualistic view will be utilised (which will be called the dualistic engagement perspective), on the one hand, and epistemologies that maintain an organic view (which will be called the organic transformative perspective), on the other hand.

\section{The impact of epistemologies anchored in a dualistic engagement perspective on defining the role of prophetic action in the private-public tension}

A dualistic approach (as for instance expressed in the so-called Two Kingdoms Model) distinguishes between the redemptive sphere of the spiritual kingdom (finding

8. Vorster's (2010 or 2012?) discussion takes place in the context of his assessment of Treisman's hypothesis that countries with an effective legal system and legal culture and countries with a Protestant tradition will have a lower incidence of corruption (see Treisman 2000:399-457). institutional expression in the present age only in the church) and the non-redemptive sphere of the civil kingdom (that encompasses non-ecclesiastical cultural endeavours as they are expressed, amongst others, in the work of the state). Social life is grounded in God's work of creation and providence and not in his work of redemption. God as creator and sustainer of life rules the civil kingdom, but its sphere is limited to earthly and temporal matters. This sphere is legitimate but not necessarily holy. The spiritual kingdom introduces the sphere of redemption in Christ and is focused on the ultimate things of Christ's eschatological kingdom. Whilst in the church, we feast on the Word of God's revelation. In our cultural lives in this temporal world, we live by the 'universally accessible' dictates of natural law ${ }^{9}$ (VanDrunen 2010:14, 15).

This dualistic view, as it functions in reformed confessional communities, draws support from a certain interpretation of the views of Calvin regarding the difference between the heavenly and earthly spheres. Calvin's views are interpreted as identifying the church with the redemptive kingdom of Christ and denouncing the claim that civil government is part of this redemptive kingdom (McIlhenny 2009:78; VanDrunen 2010:4). The Two Kingdoms Model work with an interpretation of Calvin's distinction between earthly things and heavenly things. 'Earthly things' are those which do not pertain to God or his Kingdom, to true justice or to the blessedness of future life. These earthly things are related to the present life and in a sense confined within its bounds. Spheres like public government, household management and liberal arts are included in the jurisdiction of the 'earthly things'. 'Heavenly things', in contrast, have to do with the pure knowledge of God, the nature of true righteousness and the mysteries of the Heavenly Kingdom (Calvyn [1559] 1991/1992:2, 2, 13-15).

It must be made clear that the Two Kingdom Model's distinction between the redemptive and civil spheres does not imply that the civil sphere is seen as a neutral terrain, devoid of guiding presuppositions. Although the task of the state, for instance, is to administer justice and not to preach the gospel, this justice includes protecting a citizen's right, according to civil law, to preach the gospel. Justice administered by the state also does not only include the regulation of individuals in society but also, according to the natural law written in all human hearts, the protection of harmony in the temporal world and fairness in the economic sector in adherence to God's creation order. All callings outside of the church follow the goal of living in accordance with God's created order and exercising justice in some way (McIlhenny 2009:79, 80).

\section{The implications of a dualistic engaging perspective for visualising the role of prophetic action in the private-public tension}

Christian engagement with civil society is visualised from the perspective that common ground can exist between

9. Natural law, as presented amongst others in Romans $2: 14-15$ is seen to be part of the created order and inscribed on the hearts of all. These creational laws are seen to be distinct from the special revelation of God's law to his chosen people in as far as the former do not save (Mcllhenny 2009:77). 
Christians and non-Christians in as far as both are conscious of the natural laws of God for his created order as it is written in their hearts.

Prophetic action is seen as witnessing pertaining to the issues that need to be addressed in enhancing justice and order in this temporal life and as prayers for government officials who are in need of wisdom in order to establish a peaceful and stable society, a society where all communities can serve their God without hindrance. A prophetic vision for the future of society proceeds from the idea that only Christ can truly renew (transform) society when he returns, and it consists of groaning that longs for consummation whilst bearing witness to a lost and dying world.

Corruption is seen as an evil that seriously threatens the stability and sustainability of society. A prophetic appeal is made in the context of natural law for civil leaders to act responsibly and for the activation of legal processes that promote penultimate stability-creating righteousness. These forms of engagement are, however, undertaken with the deep sense that only Christ will be able to ultimately eradicate all corrupt elements from creation upon his return.

Church leaders who proceed from this perspective should be aware of the possible one-sidedness into which their mind-set and actions can be drawn in a dualistic configuration of the private-public tension. The private space (associated with the redemptive sphere and eternal value) can become a sanctuary against deep contact with a corrupt world (in its association with things that have only temporary value), a comfort-zone that protects the spiritual community from exposure to the painful complexity and depth of suffering that people have to experience due to factors like social inequality and marginalisation. When engagement with cultural life is seen from a mind-set that reasons: 'the best we can hope for is an ordering that is natural, not Christian', the scope of the Christian contribution to society can become limited to formal, minimal and even apathetic contact (cf. Smith 2012:123). Criticising VanDrunen's Natural Law and Two Kingdoms theory, Kloosterman (2010) states:

VanDrunen is correct to warn us of the toxin of triumphalism arising from an over-realized eschatology that sees our efforts as establishing and ushering in the kingdom of God. There is another danger, however, this one equally toxic, namely, ingratitude arising from an under-realized eschatology that refuses to extend the third use of the law ${ }^{10}$ beyond personal ethics into social-cultural relationships, an ingratitude that quarantines the active rule of King Jesus, and a communal principled response to it, to the church parking lot. (p. 173)

\section{The impact of epistemologies anchored in an organic transformative perspective on defining the role for prophetic action in the private-public tension}

In Koopman's (2010b:123) approach, Christian participation in the public sphere is viewed in an organic sense by making

10. it is customary in the circles of the Reformation to speak of three uses of the law: $A$ civil use for the purpose of restraining sin, a pedagogic use to arise the knowledge of sin, and also a didactic (normative) use as the rule for the life of believers according to which they express their gratitude by loving God and their neighbours. use of an integrative trinitarian theological structure. Life is not dichotomised into 'private' (in the sense that private space serves as a retreat for individualising and spiritualising tendencies) and 'public' (in the sense that public space is seen as having only temporal or neutral value) compartments, but rather organic unity and transformative power are employed in the basic stance (Koopman 2010b):

Public theology reflects on the love of the triune God for the world. This love is expressed in the magnalia Dei, in other words, in the acts of creation, sustenance, care, election, and calling of God the Father,Mother or Parent; in the acts of reconciliation, salvation, and liberation of God the Son; and in the acts of renewal, fulfillment, and perfection of God the Spirit. This triune work establishes, confirms and actualizes the dignity and worth of all humans and of the rest of creation. God's love for the world, which comes to expression in the magnalia Dei, does have meaning, significance, and implications for all dimensions and terrains of life, from the most private, personal, and intimate to the most public, open, social, and cosmic. At its heart, therefore, Christian theology is public theology. It reflects on the love of the God who is at work in all spheres of life. (p. 123)

The agenda of public theology, according to Koopman (2010b:137), is to reflect on the contents, rationality and implications of God's love for the whole world, especially for those whose dignity is violated and who suffer exclusion, exploitation and expendability. It should also consider a creation that is killed by greed and consumerism.

Koopman's agenda for, and encompassing and deep involvement in, the public sphere is also reflected in De Gruchy's (2004) vision for the active role of the church in the transformation of the democratic South-African society:

The task of the church in society is, after all, not to confirm the status quo, however good it may be, but to seek its ongoing transformation, however difficult. The church must surely prefer a democratic society to one that is totalitarian, but its task is not primarily to legitimate democracy. Rather, it is to inject into a democratic system a vision that pushes democracy beyond its present achievements towards a greater expression of what we believe is God's will for the world. (p. 59)

Transformative action in a space where ecclesial and civic life is viewed to be representative of one undividable reality is, however, not an uncomplicated, tension-free matter. Private space (as a space in which the own ethos finds free expression) can be pressurised into becoming a space with a contra-cultural edge, or into positioning itself as an authoritative base for Christianising culture. It can also be pressurised into opening itself up to the ethos of other interest groups in the public arena in an attempt to play a compelling role. Aspects like presuppositions about the incommensurability between own values and the values of other role-players in the arena of public engagement, fears about the own truth claims being rejected and concerns about accommodative action possibly leading to self-destruction, make this a complicated field to navigate.

There are a myriad of possible responses to the tension between the own ethos and the interests of other role-players 
when the role of Christianity is basically seen to consist of an organic, transformative presence in civil society. On the right-hand end of the spectrum (the end that reflects the views of those who seek to reassert the voice of religion in society), voices like the philosopher MacIntrye and theologians Hauerwas and Milbank challenge the modern notions of common reason and experience and are generally suspicious of modern democracy (Meyer 2010:4). Hauerwas, for example, rejected the idea of universal ethic or common morality grounded in natural law. Nevertheless, he called for a kind of Christian activism in this world, that is, peculiar to Christianity. He sees the role of the church as a community of faith to live out its existence and hence display to the world how the peaceful kingdom of God provides an alternative to politics built upon violence and falsehood (VanDrunen 2010:8). On the other end of the spectrum (the end that affirms modern secularity), reference can be made to Gustafson's 'accountability theology' and Niebuhr's 'pragmatic theology' that share the attempt to make theology intelligible and at least partly credible to the wider culture in the modern world. Working with an underlying acceptance of the modern denial of metaphysics, both leave the metaphysical claim about the reality of God embedded in the background as a critical but unsubstantiated assumption (Meyer 2010:13).

For the purpose of this article (which presents itself as an overview of epistemologies that will likely have an influence on prophetic action in the landscape of South-African public theology), the focus will be on the Neo-Calvinist Approach at the one end of the spectrum and the Communicative-Rationality Approach at the other end. The first approach functions with a more critical stance in the public arena and will to a greater extent stress the non-negotiability of Christian ethos. The latter functions with a more dialogical stance and will be open for the idea of seeking universal contact points between Christianity and other views.

\section{An overview of the Neo-Calvinist Approach}

The Neo-Calvinist Approach is usually associated with a particular interpretation of the philosophies of Kuyper and Dooyeweerd. ${ }^{11}$ One of the main ideas by Kuyper that is incorporated into Neo-Calvinist thinking is the notion that every person has a faith commitment and beliefs (belief-dispositions) situated at the core of his or her being. All humans are inescapably religious. Not only Christians are believers, but people who think that they can remain religiously neutral also have belief although it may be, due to the effect of sin, a malformed belief. There cannot be such thing as absence of belief. There are only two kinds of people: On the one hand, there are those who, through divine grace,

11.It should be noted that the ideas of Kuyper and Dooyeweerd about the church's participation in society have been interpreted quite differently in other contexts. Vorster (2010:434, 435), for instance, shows how a particular interpretation of Kuyper's and Dooyeweerd's distinction between the church as 'institute' and as 'organism' led churches of the Afrikaans reformed tradition (in earlier interpretations of its Dutch roots) to limit the institutional role of the church to the ministry
of the Word and Sacraments in the official gathering of believers. The church (at of the Word and Sacraments in the official gathering of believers. The church (at emphasis on the institutional character of the church, the role of believers in their organic presence in all circles of life (the church as "organism') was not worked out fully. It is likely that this interpretation, together with the influence of Methodism, led to an initial reluctance in voicing a clear prophetic witness against the policies of the apartheid government in the pre-democratic era. know God and therefore apprehend a fundamental aspect of what reality is like as a whole. On the other hand, there are all other persons who remain in a state of malformation, do not have a capacity for the knowledge of God and lack the ability to obtain a conception of the whole. For Kuyper, cultural activity reveals the presuppositions of those who submit to the Lordship of Jesus Christ over every area of life in contrast to those who suppress that reality in unrighteousness (Wolterstorff 2001:281,282; Meyer 2010:568). The implications for participation in the public arena are clear: The Christian worldview will be seen as the only view that is able to grasp the reality of God's presence in this world and the purpose of life in its fullness. The idea of public debate on the common ground of a rationality that vies to interpret the world as a whole will therefore not be possible. In this respect, the Neo-Calvinist Approach corresponds to what Simpson (2002:137) calls the agonistic view (from the Greek agōn), a view in which the public space is seen as the site of competitive struggle to demonstrate the self-sufficient superiority and cohesive totality of virtue attributed to a particular tradition.

The profile of the Neo-Calvinist Approach's incorporation of the ideas of Kuyper also corresponds with the second characteristic of the agonistic view mentioned by Simpson (2002:137), namely that a tradition's moral virtuosity will vie for pre-eminence over other communal traditions by displaying itself as publicly as possible. In a Neo-Calvinist interpretation of Kuyper's ideas (as it occurs for instance in adaptations of Kuyper's ideas in wider American evangelicalism ${ }^{12}$ and in later developments in South African reformed circles ${ }^{13}$ ), the Christian's role in public life is seen as participation in a transformative kingdom project undertaken by a people fuelled by grace and informed by revelation's claims about how things ought to be (Smith 2012:123). The call to Christians will then be to oppose the antithetical worldview of modernism and to defend their own sanctuary by placing in opposition and publically displaying a life and worldview of their own (McIlhenny 2009:81). Christians will then not isolate themselves from the public arena and will not together with the groaning creation merely wait upon redemption. They will rather actively engage culture in order to further along its liberation. Interpreting the cultural mandate (Gn 1:26-28) from the vantage point of a creation-fall-redemption thinking scheme, Wolters $(2005: 63,71)$ reasons that redemption in Christ restores and renews human beings in their on-going cultural mandate, purging them of their sinful perversion of culture and redirecting them in ways that are obedient to God and beneficial to one another and the whole of creation. All cultural labour is seen to be kingdom work in the sense that the eschatological kingdom of God is already present in this world. Kingdom service done in the name of Christ, striving 12.See, for instance, Colson and Pearcey (2004) and Belcher (2009).

13.Discussing the impact of the view on the kingdom of God as an already-present, but not yet consummated-reality as it was worked out by scholars like Van der Walt (1962), Bright (1963) and Ridderbos (1969). Vorster (2010:446) explains how it came to be that the official ministry of the church was seen as to function like a power station, equipping believers for their work in influencing all spheres of society with the light and ethics of the kingdom. This work was seen as a form of participation in the coming of the kingdom. See Smit (2003:237) for more sources on the manifestation of Kuyper's influence in the South-African context. 
for healing justice and intellectual light in darkness, is seen to be work that has eternal value and that will be preserved in the new life. All of it lasts; none of it is wasted or lost. There are both cultural continuity and transformation in the link between this world and the next (Plantinga 2002:137-138).

\section{An overview of the Communicative Rationality Approach}

Another model for organic transformative engagement between Christianity and the public square, as discussed by Simpson (2002:139), envisages participation in a communicative civil society. ${ }^{14}$ Unlike the agonistic view, with its characteristic practices of elitist moral display or the liberal view that seeks to exclude theological traditions from bringing their private moral concerns into the public forum, communicative civil society holds that claims to practical moral truth must be redeemed critically through participatory practices. A communicative civil society anticipates overlapping moral insights. This anticipation depends on thick moral traditions becoming socially embodied and mutually engaging according to rational communicative procedures and by means of communicative practices. Such a communicative civil society is open to the prophetic vocation of congregations, exercised in their role as public companions in the public sphere rather than heroic individualists, reminding civil society of the fallibilist character of every moral consensus within a Christian eschatological horizon of the 'not yet'.

De Gruchy (2004:59) clearly points out the demands that have to be met by the rationality with which a thick moral tradition enters the public debate. He reasons that an authentic public theology will have to be self-critical and sensitive to other perspectives and approaches as well as to the historical context in order to function in the market place and public square. Yet, this has to be done in a way that does not deny its specific Christian content or undermines prophetic clarity and responsibility. He argues that there is a fine line between a theology that is arrogant and triumphalist in its witness and a theology which seeks to bring insight into the debate and, when necessary, to speak the truth clearly and unequivocally in the most concrete way possible.

As an example of how a mutually enriching exchange is visualised for public debate in a pluralistic context, reference can be made to Koopman's application of Stout's $\mathrm{s}^{15}$ perspectives on the function of language in creative ethical thinking. Koopman (2010a) writes:

14.In the conceptualisation of a communicative civil society, reference is frequently made to Habermas's theories regarding discourse in the public sphere. Habermas (1998:360) describes the public sphere as a social space generated by communicative action, as a network for communicating information and points of view. The streams of communication are, in the process, filtered and processed in such a way that they coalesce into topically specific public opinions.

15.Stout (1990:74-81) alludes to Levi-Strauss's use of the term bricolage when describing moral bricolage as an activity that involves taking apart, reordering, weighting, weeding out and filling in available conceptual resources for solving problems. Fragments of moral language are rearranged in relation to each other and the whole. In the process of bricolage, the sparse language of pidgin (a sparse dialect used entirely for communicating with members of another group, a handy mode of discourse with strangers) can undergo further development, catch on as a language to be learned in infancy and function as subtle medium for deliberation and discourse with friends and family. Linguists call such language a creole. A creol can become, over time, as rich a moral language as one could want - drawing vocabularies from different sources and weaving them together, if all goes well, into a tapestry well suited to the needs of a time and place.
We act as bricoleurs who developed a common human rights language by borrowing from various religious and secular traditions. The pidgin language, i.e. the human rights language, which served as the minimum consensus of the plurality of South-Africans over the last twelve years, developed into a creole language. That means the South-African public human rights discourse is enriched by various traditions. Christianity helped to make notions like reconciliation and restorative justice part of the new public language, or creole. And the indigenous African cultures helped to make $u b u n t u$, the notion that one person is a person through other persons, the notion therefore of communality and solidarity, part of the common creole language. (p. 46)

\section{The implications of an organic transformative perspective for visualising the role of prophetic action in the private-public tension}

In the case of the Neo-Calvinist Approach, Christian engagement with civil society is visualised from the perspective that, due to incommensurable differences at the deep level of belief dispositions, the core values of Christianity will not be negotiable in the public arena. Ultimate progress in the public arena can only be made when unregenerated thinking is transformed into becoming conscious of and bowing before the Lordship of Jesus Christ over all areas of life.

Prophetic action is seen from the perspective of its transformative contribution towards society in its present form, a renewal of society that can find its true source of liberation, righteousness and integrity only in the redemptive presence of Jesus Christ. A prophetic vision for the future of society proceeds from the idea that the kingdom of God is already breaking through into the present society, bearing the first fruits of eternal life and in the process energetically preparing this world in anticipation of its ultimate consummation.

Corruption will be seen as a manifestation of the corrupt and disintegrative forces at work in a society that can only be truly renewed when the roots of this problem is addressed by ministering the redemptive presence of Jesus Christ. Critical prophetic action will not only call for legislative measures as this will merely touch the surface of the problem. What is needed is change of heart at the deepest level of human existence and the creation of a despondency-fighting, living hope that will display how life can flourish in a sustained form in spaces where the authority of Christ is recognised in anticipation of his consummative return.

Church leaders who proceed from this perspective should be aware of the possible dominating position into which their mind-set and actions can be drawn in an open and dialogical configuration of the private-public tension. When engaging public life from a strong sense of conviction, church leaders find themselves in the predicament that they think that they are right but with no generally accepted measure by which their rightness (regarding sinfulness 
and need for redemption in Christ) can be independently validated (Bond 2010:69). Entering the public arena with a fully-fledged and comprehensive agenda for transformation (as it was comprehensively worked out in the authoritative private space) will seriously impede or even close down the possibility of making the own belief intelligible by means of a rational exchange of ideas (cf. Hermans 2005:222). Church leaders should be conscious that they are navigating a field of tension in which there is a hairbreadth of difference between a coercive imposition of the own agenda and an authentic communication of a vision that serves the common good of humanity and creation.

In the case of the Communicative Rationality Approach, engagement with civil society is visualised from the perspective that moral truth must be redeemed critically through participation in a rational dialogue with the assumption that common ground exists for open flow between Christian and non-Christian moral insights and indigenous communal experience.

Prophetic action focuses on bringing richer perspectives to points of communality in the public space. Common points of reference, like a mutual commitment to a Bill of Human Rights in a democratic society, is utilised in developing richer perspectives on aspects like restorative justice, reconciliation, equality, human dignity and the responsible deployment of available resources. An attempt is made to balance respect for the wisdom and fundamental value imbedded in other cultural and religious traditions with boldness in offering unique and ennobling insights believed to be present in the Christian tradition.

Corruption is seen as an infliction that can only be countered effectively from the communal repository of wisdom and deeply rooted indigenous insights regarding the integral functioning of civil life. Rather that imposing an artificial solution from outside or above, the deeply rooted indigenous sources for integral social life should be re-activated and ennobled. The deeply rooted culture of $u b u n t u$, for instance, can be ennobled to become an organic base for transformation once it has been liberated from apartheid effects like displacement and entitlement.

Church leaders who proceed from this perspective should be aware of the possibility that the 'otherness' of the Gospel (as for instance expressed in Jesus's emphasis on the unique righteousness that should be ministered in kingdom activity (Mt 5:20,43-48)) can become subject to dissolution in an open and dialogical configuration of the private-public tension field. Unless accompanied by robust affirmation of specific Christian identity, as Volf (2011:94) reasons, accommodation can carry in itself seeds of Christian self-dissolution. In shifting the focus of attention to an accommodating mind for the 'otherness' of other marginalised traditions, the departure point in the 'otherness' of the Gospel can begin to fade into the background. In overreaction against a coercive implementation of kingdom proclamation, the prophetic word can begin to dissolve into a wager about truth, constantly renegotiating the own truth wagers in light of popular beliefs, symbols, narratives and myths (Bond 2010:80).

\section{Conclusion}

Negotiating the tension between private and public in an attempt to engage faithfully and authentically with civic society is no easy task for the contemporary church leader. Distortions in this tension can severely impede and misalign the prophetic action of the church, whether it is by isolating redemptive action into the private sphere and limiting public engagement to a formal and superficial level in the process, or by departing from a pre-constructed and closed vision for a transformative kingdom presence in this word and having to deal with unresponsiveness against what is deemed to be coercive action in the process or by opening up to the 'otherness' of this world to such an extent that the 'otherness' of the own ethos dissolves in an ocean of undifferentiated relativity.

To my mind, the true centre of gravity for faithful and authentic engagement with civic life in our contemporary society does not primarily lie in the systematic soundness of our private theological designs for Christianity's presence in this world or in our capacity to make ourselves presentable according to what is expected from us by civil society. Our true centre of gravity rather lies in the living, pneumatological presence of and faith-union with the One to whom all things belong and Who is in the process of making all things new. Christian identity, as Volf (2011:95) reasons in his account of internal difference as a mode of Christian identity and engagement in contemporary societies, is not established by denying and combating what is outside but by embracing and highlighting the centre of what is inside - Jesus Christ as the Word who took on flesh and became the Lamb of God bearing the sin of the world. In this account, Christian identity is not reactive but positive. The centre, not fear of others, defines the difference, either of their uncomfortable proximity or of their dangerous aggressiveness.

The prophetic role of Christian communities, their engagement to mend the world, to foster human flourishing and to serve the common good, is nothing but their identity in Christ projecting itself outward in word and deed (Volf 2011:96).

By anchoring their identity in the pneumatological presence of Christ, Christians will be able to see this world and the disintegrative, corruptive forces at work in it through the eyes of Christ. They will see the full, unbearable truth about the brokenness of this world in the blazing light of God's holy vision for life and his holy will to restore this life to the fullness he intended for it in Christ. It is only along this way that our vision for the prophetic role of Christianity in civil life will not be anchored in our constructs about what the presence of God's kingdom in this world should entail or in what is expected from us by the world but in what God himself intends for his world. 


\section{Acknowledgements Competing interests}

The author declares that he has no financial or personal relationship(s) which may have inappropriately influenced him in writing this article.

\section{References}

Baker, C.R. \& Reader, J., 2009, 'Mapping the new theological space: From blurred encounters to thresholds of transformation', in J. Reader \& C.R. Baker (eds.) Entering the new theological space: Blurred encounters of faith, politics and community, pp. 219-229, Ashgate, Farnham.

Belcher, J., 2009, Deep church, InterVarsity, Downers Grove.

Bond, L.S., 2010, 'Preaching and public theology: Reclaiming the church's ministry', Encounter 71(1), 63-80.

Bright, J., 1963, The kingdom of God, Abingdon, New York.

Calvyn, J., [1559] 1991/1992, Institusie van die Christelike godsdiens, vert. H.W. Simpson, CJBF, Potchefstroom.

Colson, C. \& Pearcey, N., 2004, How now shall we live?, Tyndale, Wheaton.

De Gruchy, J.W., 2004, 'From political to public theologies: The role of theology in public life in South Africa', in W.F. Storrar \& A.R. Morton (eds.), Public Theology for the 21ste century: Essays in honour of Duncan B. Forrester, pp. 45-62, T\&T Clark, London.

De Klerk, B.J., 2013, 'The relationship between prophetic preaching and performing the gift of prophecy in South Africa', HTS Teologiese Studies/Theological Studies 69(1), Art. \#1369, 8 pages.

Habermas, J., 1998, Between facts and norms: Contributions to a discourse theory of law and democracy, transl. W. Rehg, MIT Press, Cambridge, MA.

Hermans, C.A.M., 2005, 'A pragmatic practical theology as public theology', in E. Graham \& A. Rowlands (eds.), Pathways to the public square: Practical theology in an age of pluralism, Proceedings of the International Academy of Practical Theology, Manchester, 2003, pp. 219-228, LIT Verlag, Münster.

Kloosterman, N.D., 2010, 'A response to "The kingdom of God is twofold": Natural law and the two kingdoms in the thought of Herman Bavinck by David VanDrunen', Calvin Theological Journal 45(1), 165-176.

Koopman, N., 2010a, 'Churches and public policy discourses in South Africa', Journal of Theology for Southern Africa 136(1), 41-56.

Koopman, N., 2010b, 'Some contours for public theology in South Africa', International Journal for Practical Theology 14(1), 123-138. http://dx.doi.org/10.1515/ ijpt.2010.9

Mayson, C., 2000, 'Listening for the prophetic voices: Where have all the prophets gone? Prophetic silences and the incapacity of religions to take us forward', in C.W. du Toit (ed.), Violence, truth and prophetic silence: Religion and the quest for a South-African common good, pp. 55-81, UNISA, Pretoria.
Mcllhenny, J., 2009, 'Third-way reformed approach to Christ and culture: Appropriating Kuyperian neo-Calvinism and the two kingdoms perspective', Mid-America Kuyperian neo-Calvinism and the
Journal of Theology 20(1), 75-94.

Meyer, W.J., 2010, Metaphysics and the future of theology: The voice of theology in public life, Pickwick Publications, Eugene, OR.

Miller-McLemore, B.J., 2005, 'Pastoral theology and public theology', in E. Graham \& A. Rowlands (eds.), Pathways to the public square: Practical theology in an age of secularism, Proceedings of the International Academy of Practical Theology, Manchester, 2003, pp. 95-106, LIT Verlag, Münster.

Pieterse, H.J.C., 2000, 'Where have all the prophets gone? Prophetic silence and the incapacity of religions to take us forward', in C.W. du Toit (ed.), Violence, truth and prophetic silence: Religion and the quest for a South-African common good, pp. 82-97, UNISA , Pretoria.

Plantinga, C., 2002, Engaging God's world: A Christian vision of faith, learning and living, Eerdmans, Grand Rapids, MI.

Ridderbos, H., 1969, The coming of the kingdom, Presbyterian and Reformed Publishing, Philadelphia.

Simpson, G.M., 2002, Critical Social Theory: Prophetic reason, civil society and Christian imagination, Augsburg Fortress Press, Minneapolis, MN.

Smit, D., 2003, 'Can we still be reformed? Questions from a South African perspective', in W.M. Alston Jr. \& M Welker, (eds.), Reformed theology: Identity and ecumenicity, pp. 233-253, Eerdmans, Grand Rapids, MI.

Smith, J.K.A., 2012, 'Reforming public theology: Two kingdoms, or two cities?', Calvin Theological Journal 47(1), 122-137.

Stout, J. 1990, Ethics after Babel: The language of morals and their discontent, James Clarke \& Co, Cambridge.

Transparency International, n.d., Transparency International Corruption Perceptions Index 2012, viewed 23 July 2013, from: http://cpi.transparency.org/cpi2012/ results/\#sthash.lupCFgQJ.dpuf

Treisman, D., 2000, 'The causes of corruption: A cross-national study', Journal of Public Economics 76(1), 399-457. http://dx.doi.org/10.1016/S0047-2727(99)00092-4

Van der Walt, T., 1962, Die koninkryk van God-naby!, Kok, Kampen.

VanDrunen, D., 2010, Natural law and the two kingdoms: A study in the development of reformed social thought, Eerdmans, Grand Rapids, MI.

Volf, M., 2011, A public faith: How followers of Christ should serve the common good, Brazos Press, Grand Rapids, MI.

Vorster, J.M., 2010, "n Ekklesiologiese model vir die bediening van versoening in ' $n$ sosio-politieke konteks,' In die Skriflig 44(2), 429-454.

Vorster, J.M., 2012, 'Managing corruption in South Africa: The ethical responsibility of churches', Scriptura 109(1), 133-147.

Wolters, A.M., 2005, Creation regained: Biblical basics for a reformational worldview, Eerdmans, Grand Rapids, MI.

Wolterstorff, N.P., 2001, 'What New Haven and Grand Rapids have to say to each other', in Seeking understanding: The Stob Lectures, 1986-1998, Calvin College and Calvin Theological Seminary, pp. 251-293, compiled by Calvin College and Calvin Theological Seminary, Eerdmans, Grand Rapids, MI. 